\title{
Book review of my life among the deathworks
}

\author{
Volume 6 Issue 6 - 2017
}

\section{Opinion}

This is a non-Catholic's The Catholic as Historian by Donald D'Elia \& Patrick Foley (well recommended) and, therefore, another erudite analysis of contemporary anti-transcendental existence, only Deathworks describes the end results of a world without Catholic history. Reiff writes that we live in a world of "permanent negation" (page 33) - the denial of the sacred and a relativity which basically means, "anything goes if you are loud enough."

Reiff's clarifications ring true: a neat splitting of cultures into pagan (first world), Judeo-Christian (second world-Reiff wrongly includes Islam which truly is first world as he defines it), and deathworks (the predominating third world of today). "Transgressively, kindly tosh. Liberalism has turned tragedy and transgression, pagan and Christian, into the biggest con game in the Western town; that game directed by toshmasters in academical gown" (page 72). And "third world creation" is "the act of de-creation" (page 98). All is banalized by secularism/atheism:

"Sacrament is a fusion with the highest and the central event in the dramaturgical enactment of highest authority. The sacrament as fusion with the highest authority is inverted to the image in Piss Christ as a fusion with the lowest. The highest is identified down in an act of incredible crudity. It amounts to an assault that lowers the Catholic identity of Galatians 2:20 to the level of excrement. Christ is in you, and so you are piss. The excremental assault on the Jews in the middle of the twentieth century is here repeated on Catholics. The alternative to such an identity is an aesthetic identity of race, class, gender, or bagels and lox (page 98)."

\section{Reiff spares not homosexuality:}

"The whole language of homosexuality is a form fusion mythology that reduces the irreducible and must be a form of destruction through mendacity. Every being in either its hereness or thereness is a mode of resistance and completely different from myself. Any effort to reduce that difference, or equalize it, is oppressive and false. But we have sacrificed the clear and distinct Being there to a fiction of equality and of community that cannot obtain in reality" (page 124-125).

Believe: the deathworks are made discouragingly clear by the anus of Mapplethorpe (picture included) as the incontrovertible acme of the secularism /atheism culture foisted on us by almost all information technology from the New York Times to Hollywood. I cannot believe we are living in this miasma in which The Fall has to be bottoming out. So to help Easter arrive, I must offer the following:

Technology in all its forms has been removing the planetary, human and divine components of existence by denying that the transcendentals are significant. Matter, identity, truth, oneness, good and beauty are replaced by an artificial virtual reality excitement emanating from the dehumanizing denaturizing electrono-celluloidinkstool miasma. Thereby, reality is replaced and polluted by nonbeing. That is, since God and sacred are forbidden, juvenile immaturity never ceases. Therefore, in the practical order, "anything goes" by the ultimate inane pseudofreeing nihilistic massively selfish pollution paradigm of "sperm everywhere" (Squirt/moan and slime/squeal truly

\author{
Samuel A Nigro M.D \\ Retired, Assistant Clinical Professor Psychiatry, Case Western \\ Reserve University School of Medicine, USA
}

\begin{abstract}
Correspondence: Dr. Samuel A Nigro M.D., Retired,Assistant Clinical Professor Psychiatry, Case Western Reserve University School of Medicine, 2517 Guilford Road, Cleveland Heights, Ohio 44I 18, USA, Tel 216 932-0575, Email sam@docnigro.com

Received: June 20, 2016 | Published: July 06, 2017
\end{abstract}

represent the permanently adolescent intellectual-emotional acme of all secularism/atheism and its culture of disgust, nipples, squirt and death.)! The answer is to denature, derealize and dehumanize the electrono-celluloid-inkstool miasma as not only non- but antitranscendental, and therefore the press and media are more unworthy of belief or imitating than that which they deny existence and try to destroy. De-be the stool miasma by overt and covert mocking and the imposing of the same arrogant decreating created by technologically based secularism/atheism imposed by today's unchilding powermad liberals straight out of Orwell's 1984. Unfortunately, when dealing with filth, disgust and death, one must get dirty. But "Tu quoque!" is the cry. On all produced for the public should be the label "The press and media are harmful to your health." The denaturing must be denatured. The dehumanizing must be dehumanized. The meaninglessness must be made meaningless. The deniers must be denied. The nihilists must be nihilized. The excitement must be made laughable by gross biologolizing i.e., global f--king is much more polluting than global warming, and non-marital (non-sacramental) sex is really just a form of toileting. Until genital misuse is mocked, sexuality for humans will be unplanetary pollution and never normal as in the rest of the animal kingdom naturally following nature. The liars for whom all truth is relative must be lied about ("relativized"). The frauds of science (all of them) must be shown to be the pretending hypocrites they all are. In short, the electrono-celluloid-inkstool miasma must never be considered credible unless transcendental. So drown the press and media in its own fake liberal openness to all as it censors and represses God, the Church and the transcendental theory of the Universe. Overthrow the dictatorship of the press and media and all the unreality people. Doing such is charitable, decent and transcendental especially for impressionable, gullible and suggestible youth. With the mention of every celebrity ("look at me" fakers from permanent makeup to "don't have'em" bowel movements) and every newspaper electronocommunications gaggle, youth must giggle. I volunteer. Never write or say "The New York Times" Instead, it is the "New Yuk Slime." Do the same for all the press and media and all celebrities of secularism/atheism. Use your imagination and call 
it "truth" as secularists/atheists do. Puns will help. It will get worse. Make it so. Always demean and degrade secularism/atheism and the stool miasma press and media. The children you prevent them from kidnapping may be your own.

The Deathworks are here. Needed are The Catholic as Historian and my pamphlet ... and Satan turned into an Angel of Light...

Everyone must stop being so suggestible and gullible-it is death. And without the transcendentals, there is no love, no culture worthy of the name, no virtue, and no nobleness - just secularism/atheism and a dirty-minded schoolboy culture of meaningless excitement and degrading disgust.

It is time to really understand "evolution": However you act in this life is what will be done to you in the Afterlife magnified by at least 1000 . And by The Deathworks, your every sin will be massively received "payback" in return, permanently if mortal, Purgatorily if venial. If in Hell, it will be a never ending infernal recycling selfcreated self-annihilation by your own sins turned against yourself. If in Purgatory, it will be a restoring reliving of one's reparable sins being done to oneself. And, if in Heaven, it will be a true, one, good and beautiful ecstasy proportional to your own lived truth, oneness, goodness and beauty. This is real evolution.

\section{Acknowledgments}

None.

\section{Conflicts of interest}

None.

\section{Funding}

None. 